\title{
Analisis Pendapatan Usahatani Jagung pada Kelompok Tani Oelbubuk di Desa Oeolo Kecamatan Musi Kabupaten Timor Tengah Utara
}

\author{
Alfrida Karbaju $u^{\mathrm{a}}$, dan Adeline Norawati Hutapea ${ }^{\mathrm{b}}$ \\ ${ }^{a}$ Fakultas Pertanian, Universitas Timor, Kefamenanu, TTU - NTT, Indonesia. \\ ${ }^{b}$ Fakultas Pertanian, Universitas Timor, Kefamenanu, TTU - NTT, Indonesia.
}

\section{Article Info}

Article history:

Received 11 Juni 2017

Received in revised form 16 Juli 2017

Accepted 15 Oktober 2017

\begin{abstract}
Abstrak
Jagung di pulau Timor masih menjadi bahan makanan pokok bagi sebagian besar masyarakat di pedesaan sehingga selalu dibudidayakan pada saat musim hujan. Tujuan penelitian ini adalah untuk mengetahui 1) gambaran usahatani jagung; dan 2) pendapatan usahatani jagung Kelompok Tani Oelbubuk di Desa Oeolo Kecamatan Musi Kabupaten TTU. Penelitian dilaksanakan di kelompok tani Oelbubuk, desa Oeolo, Kecamatan Musi, Kabupaten TTU, pada Bulan Januari sampai Agustus 2016. Teknik pengambilan sampel dalam penelitian in menggunakan teknik sensus sehingga semua anggota kelompok tani menjadi responden yakni 20 responden. Untuk menjawab tujuan pertama digunakan metode analisis deskriptif kualitatif, sedangkan untuk menjawab kedua dilakukan analisis pendapatan. Hasil penelitian menunjukkan bahwa jagung yang dibudidayakan adalah jagung lokal yang dipersiapkan dari musim panen tahun lalu. Persiapan lahan dilakukan dengan memilih lahan yang akan mencukupi bagi seluruh anggota kelompok tani selanjutnya melakukan pembersihan dengan sistem tebas bakar pada lahan yang akan diolah. Penanaman jagung dilakukan pada bulan September-November dengan membuat lubang tanam dengan kedalaman 2,5 cm dan pada tiap lubang ditanami 3-4 biji jagung dengan jarak tanam 40-50 cm. Penyiangan dilakukan sekal dalam seminggu dengan menggunakan Roundup untuk membasmi gulma yang tumbuh di antara tanaman. Pupuk yang digunakan yaitu pupuk kandang. Jagung dipanen setelah berumur 95-100 hari. Panen dilakukan dengan cara memetik jagung dalam bentuk berkelobot setelah itu jagung dijemur di bawah sinar matahari hingga kering kemudian disimpan dan hasil produksinya siap untuk dipasarkan. Produks pada musim panen tahun 2016 berkisar antara $195-250 \mathrm{~kg}$ dengan total keseluruhan produksi usahatani jagung sebesar $4.648 \mathrm{~kg}$. Total produksi yang dijual sebesar 3,448 kg dengan harga jual Rp. 3.500/kg. Total penerimaan kelompok tani Oelbubuk sebesar Rp. 12,068,000. dengan rata-rata Rp. 603.400 per anggota. Pendapatan total sebesar Rp. 5,732,500 dengan rata-rata pendapatan masing-masing anggota sebesar Rp. 286,625. per musim tanam. @2017 dipublikasikan oleh Agrimor.
\end{abstract}

\section{Keywords:}

Pendapatan

Jagung

Oelbubuk petunjuk Sugiyono, (2006), sedangkan untuk menjawab kedua dilakukan analisis pendapatan sesuai petunjuk Soekartawi, (1995).

Jagung merupakan salah satu komoditi tanaman pangan yang penting dan mengambil peran dalam pembangunan sektor pertanian. Komoditi jagung bukan hanya digunakan sebagai bahan pangan tetapi dapat dijadikan sebagai pakan ternak. Prospek usahatani tanaman jagung cukup cerah bila dikelola secara intensif dan komersial berpola agribisnis (Rukmana, 1997).

Jagung di pulau Timor masih menjadi bahan makanan pokok bagi sebagian besar masyarakat di pedesaan sehingga selalu dibudidayakan pada saat musim hujan. Selain sebagai bahan makanan pokok, jagung juga telah dijadikan sebagai bahan baku industri kecil atau industri rumahan di kabupaten Timor Tengah Utara (TTU) misalnya, Falo \& Fallo, (2016) melaporkan bahwa jagung telah dimanfaatkan sebagai bahan baku agroindustri tortila atau kerupuk jagung. Kolo \& Hutapea, (2016) juga memberikan gambaran bahwa jagung juga digunakan untuk membuat biskuit jagung.

Kecamatan Musi kabupaten TTU adalah salah satu desa yang makanan pokok masyarakatnya adalah jagung. Luas tanam, produksi dan produktivitas jagung di kecamatan Musi tahun 2013 adalah luas tanam 350 ha, produksi 887 ton dengan produktivitas 2,53 t/ha (BPS Kab. TTU, 2014), tahun 2014 dengan luas tanam 700 ha, produksi 1915 ton dengan produktivitas 2,73 t/ha (BPS Kab. TTU, 2015) dan tahun 2015 adalah luas tanam 500 ha, produksi 1045 ton dengan produktivitas 2,09 t/ha (BPS Kab. TTU, 2016). Produktivitas jagung di wilayah ini lebih tinggi dari beberapa hasil penelitian terdahulu di beberapa wilayah kabupaten TTU yakni 1 t/ha (Wonkay \& Taolin, 2016), dan 1,4 t/ha (Leki et al., 2016) tetapi lebih rendah dari 3,54 t/ha yang dihasilkan dari penelitian Bhato, (2016).

Luas tanam, produksi dan produktivitas jagung di kecamatan Musi berfluktuasi selama tiga tahun terakhir, fluktuasi hasil yang sama juga dialam salah satu kelompok tani di wilayah tersebut yakni kelompok tani Oelbubuk di desa Oeolo. Kelompok tani Oelbubuk melaksanakan usahatani jagung secara intensif dengan tujuan meningkatkan kesejahteraan para anggota. Menurut Falo, (2016), kehadiran kelompok-kelompok tani yang ada di masyarakat selalu diarahkan untuk semakin terikat oleh kepentingan dan tujuan bersama dalam meningkatkan produksi dan pendapatan dari usahataninya. Sebagai kelompok tani yang menjalankan usahatani, kelompok tani Oelbubuk telah memperoleh produksi usahatani jagung berupa pipilan kering $250 \mathrm{~kg}$ pada tahun 2013,249 kg pada tahun 2014, dan $244 \mathrm{~kg}$ pada tahun 2015 . Hal yang belum dapat dijelaskan adalah seberapa besar pendapatan yang diperoleh kelompok tani Oelbubuk dari usahatani jagung yang dijalankan, untuk itu perlu dilakukan kajian dengan topik "Analisis Pendapatan Usahatani Jagung pada Kelompok Tani Oelbubuk di Desa Oeolo Kecamatan Musi Kabupaten TTU”. Tujuan penelitian ini adalah untuk mengetahui 1) gambaran usahatani jagung; dan 2) pendapatan usahatani jagung Kelompok Tani Oelbubuk di Desa Oeolo Kecamatan Musi Kabupaten TTU.

\section{Metode}

Penelitian dilaksanakan di kelompok tani Oelbubuk, desa Oeolo, Kecamatan Musi, Kabupaten TTU, pada Bulan Januari sampai Agustus 2016. Teknik pengambilan sampel dalam penelitian ini menggunakan teknik sensus sehingga semua anggota kelompok tani menjadi responden yakni 20 responden.

Data yang digunakan dalam penelitian ini adalah data primer yang diperoleh dengan teknik wawancara langsung dengan responden atau petani berdasarkan daftar pertanyaan yang disiapkan oleh peneliti sedangkan data sekunder diperoleh dari instansi atau lembaga terkait. Data yang diperoleh dikumpulkan kemudian ditabulasi dan dianalisis berdasarkan tujuan penelitian. Untuk menjawab tujuan pertama digunakan metode analisis deskriptif kualitatif sesuai

\section{Hasil dan Pembahasan}

\subsection{Gambaran Umum Usahatani Jagung}

Gambaran kegiatan usahatani jagung di Kelompok Tani Oelbubuk, Desa Oeolo, Kecamatan Musi masih menerapkan pola pertanian tradisional, dan dapat dijelaskan sebagai berikut:

a. Persiapan Benih

Jenis benih yang digunakan adalah benih lokal yang dimiliki oleh para petani sendiri yang hanya berasal dari benih yang sudah tersedia dari tahun sebelumnya Benih yang disiapkan berdasarkan luas lahan sebesar 20 are per anggota dengan persediaan $10 \mathrm{~kg}$.

\section{b. Persiapan Lahan}

Persiapan lahan yang dilakukan di lokasi penelitian adalah dengan memilih lahan yang akan mencukupi bagi seluruh anggota kelompok tani dan melakukan pembersihan dengan sistem tebas bakar pada lahan yang akan diolah.

\section{c. Penanaman}

Penanaman jagung dilakukan secara tradisional yang di mulai pada bulan September-November dengan cara membuat lubang yang biasanya menggunakan (tugal). Kedalaman lubang tanam 2,5 cm dan pada tiap lubang ditanami 3-4 biji jagung, dengan jarak tanam 40-50 cm

d. Penyiangan

Penyiangan dilakukan satu kali dalam seminggu yaitu dengan menggunakan pestisida jenis Roundup untuk membasmi gulma yang tumbuh disela-sela tanaman. Penyiangan biasanya dilakukan pada saat tanaman berumur dua minggu.

\section{e. Pemupukan}

Pemupukan adalah salah satu kegiatan yang harus dilakukan dalam membudidayakan suatu tanaman. Dalam penelitian ini, petani responden menggunakan pupuk kandang. Dengan demikian secara ekonomis petani responden tidak mengeluarkan biaya untuk pupuk.

\section{f. Panen dan Pasca Panen}

Jagung dapat dipanen setelah tanaman jagung berumur 95-100 hari setelah tanam. Tanda-tanda yang dipakai untuk menentukan saatnya panen yaitu pembungkus jagung sudah berwarna kuning. Panen biasanya dilakukan dengan cara memetik jagung dalam bentuk berkelobot dan memisahkan biji jagung dar tongkol jagung caranya jagung dijemur di bawah sinar matahari hingga kering, kemudian isi pada tempat yang telah disediakan seperti karung dan disimpan pada tempat yang baik dan hasil produksi tersebut siap untuk dipasarkan.

\subsection{Analisis Pendapatan}

a. Biaya Produksi

Berdasarkan penggunaannya maka diperhitungkan biaya produksi yaitu biaya pestisida, biaya transportasi, biaya tenaga kerja, biaya penyusutan alat. Benih yang digunakan oleh petani di kelompok tani Oelbubuk yaitu jagung lokal yang merupakan milik sendiri dengan persediaan $10 \mathrm{~kg} / 20$ are luas lahan. 
- Biaya Variabel

Berdasarkan hasil penelitian jenis pestisida yang digunakan adalah Roundup dengan harga Rp. 75,000/liter dengan penggunaan setiap liter untuk 20 are. Biaya transportasi biasanya digunakan dalam pengangkutan hasil produksi jagung dengan besaran biaya tertinggi Rp.100.000 dan biaya terendah Rp. 35.000 dengan rata-rata biaya transportasi Rp. 67.000. Tenaga kerja merupakan salah satu input yang penting dalam manajemen usahatani jagung, dengan rata-rata biaya tenaga kerja Rp. 73.000. Media untuk menampung hasil para petani melakukan pembelian karung yang disesuaikan jumlah hasil dengan rata-rata harga karung sebesar Rp. 6,500. Perhitungan biaya variabel dapat dilihat pada Tabel 1.

Tabel 1. Biaya Produksi

\begin{tabular}{lccrr}
\hline \multicolumn{1}{c}{ Jenis Biaya } & Jumlah Anggota & Volume & \multicolumn{1}{c}{ Satuan } & \multicolumn{1}{c}{ Total } \\
\hline Pestisida & 20 & 40 liter & 75,000 & $3,000,000$ \\
Karung & 20 & 87 buah & 1,500 & 130,500 \\
Tenaga Kerja & 20 & 73 orang & 20,000 & $1,460,000$ \\
Transportasi & 20 & - & - & $1,340,000$ \\
\hline \multicolumn{5}{c}{ Jumlah } \\
\hline
\end{tabular}

- Biaya Tetap

Biaya tetap yang diperhitungkan adalah biaya penyusutan alat yang digunakan dalam kegiatan usahatani jagung yang terdiri dari parang, sabit, linggis, pacul dan tajak, dengan total penyusutan alat sebesar Rp. 81.000.

\section{b. Penerimaan}

Produksi jagung pada musim panen tahun 2016 berkisar antara $195-250 \mathrm{~kg}$ dengan total keseluruhan produksi usahatani jagung sebesar $4.648 \mathrm{~kg}$. Total produksi yang dijual sebesar 3,448 kg dengan harga jual Rp. 3.500/kg. Total penerimaan kelompok tani Oelbubuk sebesar Rp. 12,068,000. dengan rata-rata Rp. 603.400 per anggota.

\section{c. Pendapatan}

Berdasarkan besarnya biaya produksi dan penerimaan maka diperoleh pendapatan total pada kelompok tani Oelbubuk sebesar Rp. 5,732,500 dengan rata-rata pendapatan masing-masing anggota sebesar Rp. 286,625. per musim tanam. Rata-rata pendapatan anggota kelompok tani ini masih jauh lebih rendah dibandingkan pendapatan petani yang melakukan usahatani jagung di desa Bitefa kecamatan Miomaffo Timor. Menurut Kune, (2017) rata-rata pendapatan usahatani jagung di desa Bitefa sebesar Rp. 13.022.217,39.

\section{Simpulan}

Jagung yang dibudidayakan adalah jagung lokal yang dipersiapkan dari musim panen tahun lalu. Persiapan lahan dilakukan dengan memilih lahan yang akan mencukupi bagi seluruh anggota kelompok tani selanjutnya melakukan pembersihan dengan sistem tebas bakar pada lahan yang akan diolah. Penanaman jagung dilakukan pada bulan September-November dengan membuat lubang tanam dengan kedalaman $2,5 \mathrm{~cm}$ dan pada tiap lubang ditanami 3-4 biji jagung dengan jarak tanam 40-50 cm. Penyiangan dilakukan sekali dalam seminggu dengan menggunakan Roundup untuk membasmi gulma yang tumbuh di antara tanaman. Pupuk yang digunakan yaitu pupuk kandang (bokashi). Jagung dipanen setelah berumur 95-100 hari. Panen dilakukan dengan cara memetik jagung dalam bentuk berkelobot setelah itu jagung dijemur di bawah sinar matahari hingga kering kemudian disimpan dan hasil produksinya siap untuk dipasarkan. Produksi pada musim panen tahun 2016 berkisar antara 195-250 kg dengan total keseluruhan produksi usahatani jagung sebesar $4.648 \mathrm{~kg}$. Total produksi yang dijual sebesar $3,448 \mathrm{~kg}$ dengan harga jual Rp. 3.500/kg. Total penerimaan kelompok tani Oelbubuk sebesar Rp. 12,068,000. dengan rata-rata Rp. 603.400 per anggota. Pendapatan total sebesar Rp. 5,732,500 dengan rata-rata pendapatan masing-masing anggota sebesar Rp. 286,625. per musim tanam.

\section{Pustaka}

Bhato, M.A. 2016. Respon Pertumbuhan dan Hasil Jagung (Zea mays L.) Varietas Pioner terhadap Berbagai Takaran Pupuk Kandang Babi dan Jarak Tanam. Savana Cendana, 1(02): 85-89.

BPS Kab. TTU 2014. Musi dalam Angka 2014. Kefamenanu: Badan Pusat Statistik Kabupaten TTU.

BPS Kab. TTU 2015. Musi dalam Angka 2015. Kefamenanu: Badan Pusat Statistik Kabupaten TTU.

BPS Kab. TTU 2016. Kecamatan Musi dalam Angka 2016. Kefamenanu: Badan Pusat Statistik Kabupaten TTU.

Falo, M. 2016. Peran Kepemimpinan Ketua Kelompok Tani Oel'nasi, di Desa Sallu Kecamatan Miomaffo Barat, Kabupaten Timor Tengah Utara. AGRIMOR, 1(03): 49-52.

Falo, M. \& Fallo, Y.M. 2016. Kajian Pendapatan Agroindustri Tortila di Kecamatan Insana Barat Kabupaten Timor Tengah Utara. AGRIMOR, 1(02): 19-20.

Kolo, D. \& Hutapea, A.N. 2016. Strategi Pengembangan Usaha Biskuit Jagung di Kelompok Wanita Tani Lestari Desa Subun Tua'lele, Kecamatan Insana Barat, Kabupaten Timor Tengah Utara. AGRIMOR, 1(03): 42-45.
Kune, S.J. 2017. Analisis Pendapatan dan Keuntungan Relatif Usahatani Jagung di Desa Bitefa Kecamatan Miomaffo Timur Kabupaten TTU. AGRIMOR, 2(02): 23-24

Leki, W., Lelang, M.A. \& Taolin, R.I. 2016. Pengaruh Takaran Pupuk Kandang Sapi Terhadap Pertumbuhan dan Hasil Jagung (Zea mays, L.) yang Ditumpangsarikan dengan Kedelai (Glysine max,(L.) Merril). Savana Cendana, 1(01): 17-23.

Rukmana, R. 1997. Usaha Tani Jagung. Yogyakarta: Kanisius.

Soekartawi 1995. Analisis Usaha Tani. Jakarta: Universitas Indonesia Press.

Sugiyono 2006. Metode Penelitian Kuantitatif, Kualitatif dan $R \&$ D. Bandung: Alfabeta.

Wonkay, R.E. \& Taolin, R.I.C.O. 2016. Pengaruh Model Penyimpanan Benih dan Jenis Pupuk Kandang terhadap Pertumbuhan dan Hasil Jagung (Zea mays L.). Savana Cendana, 1(04): 128-132. 